\title{
KELAINAN RANGKA FETUS MENCIT (Mus musculus) GALUR BALB/C AKIBAT PEMBERIAN DEET (Diethyltoluamide)
}

\author{
Wiwik Kusmawati \\ Program Studi Pendidikan Biologi FPIEK IKIP Budi Utomo Malang \\ Jl. Citandui No. 46 Malang \\ Email; wiwikkusmawati@gmail.com
}

\begin{abstract}
The study was aimed to identify the effect of DEET on fetal skeletal abnormalities of Balb/C strain mice. Thirty five female Balb/C strain mice were used in this study. The female mice were mated with male mice used one mating method. Mice in treatment group were administered dermally with 281,25; 562,51125 and $2250 \mathrm{mg} / \mathrm{kg}$ BW DEET disolved in ethanol at gestation day of 6 to 15, while mice in control were administered with ethanol. Mice in group were repeated seven times. At gestation day 18, the mice were sacrificed and fetal skeletal abnormalities were observed. Bone staining subsequently was done by using Alizarin Red S. Results were analyzed by using SPSS program version 16 personal computer, one way ANOVA and multiple comparison test with significance level of 0,05. Skeletal abnormalities such as supraoccipital, sternal, vertebral, sacrocaudal and phalanx were not found in all doses administered. From these experiment we suggested that DEET has no effects in fetal skeletal abnormalities such as supraoccipital, sternal, vertebral, sacrocaudal and phalanx.
\end{abstract}

Keywords: DEET, Fetal skeletal abnormalities

\section{PENDAHULUAN}

Diethyltoluamide (DEET), dikenal dengan nama produk dagang Autan, Detamide, Metadelphen, Repper-det, Repladin Special, Oldtime Woodsman, Cutter, Muskol, Chemform, Baker's Antifol ataupun Off. DEET mempunyai nama kimia diethyl-mtoluamide; diethyl-meta-toluamide; N,Ndiethyl-3-methyl-benzamide ataupun 3-methylN,N-diethylbenzamide (Cecchine, et al., 2002; Anonim $^{1}$, 2002; Anonim ${ }^{3}$, 2002). DEET merupakan pestisida kelompok pengusir serangga (insect repellent). DEET ini termasuk kelas kimia aromatic amide yaitu N,Ndialkylarylamide (Anonim ${ }^{2}$, 2002; Anonim ${ }^{3}$, 2002).

Insect repellent yang mengandung DEET digunakan untuk mengusir gigitan lalat hitam, lalat kuda, lalat pasir, kutu kucing, kutu anjing, agas dan nyamuk (famili Culicidae) (Anonim $^{2}$, 2002; Anonim $^{3}$, 2002). DEET paling efektif untuk mengusir nyamuk Aedes aegypti dan Aedes taeniorhynchus (Pronczuk, 1990).

Salah satu strategi untuk memperkecil kejadian arthropod-borne disease adalah dengan menggunakan personal proteksi yaitu dalam bentuk insect repellent. DEET adalah proteksi yang paling efektif terhadap penyakit malaria, dengue fever, yellow fever, epidemic polyarthritis, encephalitis, bancroftian filariasis (Fradin, 1998; Anonim4, 2003).

Karbon dioksida dan asam laktat yang dihasilkan oleh manusia merupakan attractant yang sangat penting bagi nyamuk untuk menggigit inang. DEET mengusir nyamuk dengan penghambatan kemoreseptor pada antenanya yang distimulasi oleh asam laktat (Fradin, 1998; Cecchine, et al., 2002; Anonim $^{3}$, 2002).

Penelitian yang dilakukan Yayasan Lembaga Konsumen Indonesia (YLKI) pada tahun 1995, menemukan bahan aktif DEET pada berbagai produk insect repellent (Anonim $^{2}$, 2003; Anonim ${ }^{3}$, 2003). Produk insect repellent ini dapat membahayakan manusia karena kandungan bahan aktif DEET (Anonim ${ }^{1}, 2003$ ). Bahaya DEET adalah dapat mengakibatkan kegilaan (maniac psychosis), kejadian kardiovaskuler, alergi kulit dan dermatis (Cecchine, et al., 2002). Produk yang mengandung DEET ataupun isomernya sangatlah efektif sebagai insect repellent tetapi juga dapat mengakibatkan reaksi dermal dan neurologik pada manusia (Anonim ${ }^{1}, 2002$ ).

DEET merupakan pestisida yang sangat unik, karena dapat digunakan secara langsung pada kulit manusia dengan tujuan untuk mencegah gigitan serangga (Anonim ${ }^{1}, 2002$ ). Pada umumnya DEET digunakan pada kulit 
manusia, pakaian, hewan peliharaan, tenda, alas tidur gulungan, mesh insect nets dan kasa jendela (Fradin, 1998; Anonim², 2002; Anonim ${ }^{1}, 2002$ ).

DEET dapat terabsorpsi masuk ke dalam kulit dan dapat didistribusikan pada seluruh organ termasuk otak dan fetus (Anonim ${ }^{1}$, 2002). Senyawa ini dapat diekskresikan melalui urin (Pronczuk, 1990; Anonim ${ }^{1}$, 2002; Anonim $^{2}$, 2002).

Studi yang dilakukan terhadap tikus dengan pemberian DEET selama kebuntingan, ternyata senyawa ini dapat terabsorpsi masuk ke dalam kulit dan dapat melintasi plasenta (Pronczuk, 1990; Pergament and Amy, 1992; Anonim $\left.^{4}, 2003\right)$. DEET yang diberikan pada kulit betina albino selama kebuntingan ditemukan terdapat pada plasenta, fetus dan induk pada masa tiga bulan sesudah kelahiran (Pronczuk, 1990).

Terdapat dalam laporan kasus pada manusia tentang gambaran maternal akibat DEET dengan kadar $25 \%$ yang diberikan pada lengan dan kaki setiap hari selama kehamilan. Akibatnya bayi yang terlahir mengalami kecacatan sehubungan dengan wajah, seperti: retardasi sensorimotor, problem otot dan kehilangan pendengaran (Anonim $\left.{ }^{4}, 2003\right)$.

Pemberian DEET pada kulit tikus betina albino selama kebuntingan meningkatkan kecepatan kematian post natal dan embrional (Pronczuk, 1990). Kelinci bunting yang diberi DEET 0, 50, 100, 500, 1000 atau $5000 \mathrm{mg} / \mathrm{kg}$ $\mathrm{BB}$ dalam pelarut etanol pada tulang punggung tercukur pada umur kebuntingan ke-0 - 29 hari, menunjukkan tidak ada peningkatan kejadian anomali skeletal atau jaringan lunak yang diamati pada kelompok kontrol dan perlakuan (Anonim ${ }^{1}$, 2002).

Dari hasil penelitian, DEET dapat mengakibatkan efek teratogenik dan embriotoksik pada embrio ayam white leghorn dengan 1,27 mikromol DEET yang diberikan pada membran khorio-allantois. Sebanyak 41 $\%$ embrio dapat bertahan hidup dan $33 \%$ embrio mengalami malformasi, umumnya kejadian kardiovaskuler, muskuloskeletal dan kecacatan sistem saraf pusat (Anonim $\left.{ }^{1}, 2002\right)$. Kecacatan kelahiran akibat pemberian DEET juga terjadi pada embrio ayam domestik (Gallus gallus domesticus, famili Phasianidae: burung belibis, kalkun, ayam pegar dan ayam hutan) (Anonim $\left.{ }^{3}, 2002\right)$.

Dari uraian diatas, maka sangatlah penting untuk mengkaji efek DEET terhadap kelainan rangka fetus mencit (Mus musculus) galur Balb/C. Penelitian ini merupakan penelitian terapan yang dikerjakan secara eksperimen laboratorik dengan menggunakan hewan coba mencit sebagai model. Hal ini karena pola perkembangan embrio mencit hampir sama dengan manusia, siklus hidupnya pendek, mudah dipelihara dan cepat berkembang biak. Dengan demikian perlakuan yang diberikan kepada mencit dan hasil dari perlakuan yang didapatkan dalam penelitian ini diharapkan dapat digunakan sebagai pertimbangan penggunaan DEET pada manusia.

\section{METODE PENELITIAN \\ Mengawinkan Mencit}

Mengawinkan mencit dengan cara mencit betina dikumpulkan dengan mencit jantan dalam satu kandang dengan menggunakan metode one mating._Untuk mengetahui apakah pada mencit betina sudah dikawini atau belum, maka pada hari berikutnya setelah dikawinkan, diamati adanya sumbat vagina (vaginal plug). Sumbat vagina ini terdiri dari gelatin yang sudah menggumpal yang berfungsi untuk menjaga agar spermatozoa tidak tumpah keluar. Apabila terdapat sumbat vagina maka dapat dianggap bahwa kopulasi telah terjadi dan pada saat ini dianggap sebagai kebuntingan hari ke nol. Dengan adanya tanda kebuntingan ini, mencit betina diletakkan pada kandang individual. Nomor mencit diberikan dengan cara pemberian tanda pada bagian kuping mencit, kemudian dicatat tanggal estrus, tanggal kopulasi, tanggal pemberian DEET dan tanggal saat dikorbankan.

\section{Pembuatan Larutan}

Dosis yang digunakan pada penelitian ini adalah $0 ; 281,25 ; 562,5 ; 1125$ dan $2250 \mathrm{mg} / \mathrm{kg}$ BB. Dosis tersebut merupakan $1 / 2,1 / 4,1 / 8$ dan $1 / 16$ dosis kisaran terendah dari $\mathrm{LD}_{50}$ pada mencit yaitu $4500 \mathrm{mg} / \mathrm{kg}$ BB (Pronczuk, 1990).

\section{Cara Perlakuan}

Mencit betina bunting dikelompokkan menjadi empat kelompok (terdiri dari satu kelompok kontrol dan tiga kelompok perlakuan). Sebelum digunakan untuk pengujian, mencit tersebut selama satu minggu diadaptasikan untuk hidup bersama dalam satu kandang dan ditimbang berat badannya. Pada 
kelompok perlakuan diberi DEET dermal pada tulang punggung tercukur dengan ukuran $2 \times 2$ cm pada dosis $0 ; 281,25 ; 562,5 ; 1125$ dan 2250 $\mathrm{mg} / \mathrm{kg}$ BB pada umur kebuntingan ke-6 - 15 hari. Untuk dosis $0 \mathrm{mg} / \mathrm{kg} \mathrm{BB}$ (kontrol) hanya diberikan etanol.

\section{Pengamatan}

Pada umur kebuntingan ke-18 hari, induk mencit ditimbang kemudian dikorbankan untuk pembedahan. Pada setiap pembedahan diawali dengan pembiusan menggunakan kloroform, kemudian hewan coba ditelentangkan di atas papan seksi dan mulai dilakukan pembedahan. Pembedahan dimulai dari vagina menuju ke arah perut dengan menggunakan gunting kecil. Selanjutnya dicari uterus untuk mengeluarkan fetus dan dimasukkan ke dalam alkohol $96 \%$ untuk selanjutnya dilakukan pewarnaan rangka dengan menggunakan Alizarin Red S 0,01\%.

\section{Analisa Data}

Hasil yang diperoleh dianalisis dengan menggunakan personal komputer program SPSS versi 11 dengan ANOVA satu jalur serta uji perbandingan berganda (BNT) pada taraf signifikansi $\alpha=0,05$.

\section{HASIL DAN PEMBAHASAN}

Data rata-rata berat fetus dapat dilihat pada tabel 1 dan gambar 1 .

Tabel 1. Rata-rata berat fetus (mg) setelah pemberian berbagai dosis DEET

\begin{tabular}{|c|c|}
\hline $\begin{array}{c}\text { Dosis DEET } \\
\text { (mg/kg BB) }\end{array}$ & $\begin{array}{c}\text { Berat fetus } \\
\text { (mg) }\end{array}$ \\
\hline 0 & 0,9049 \\
281,25 & 0,5964 \\
562,5 & 0,7837 \\
1125 & 0,8979 \\
2250 & 0,6573 \\
\hline
\end{tabular}

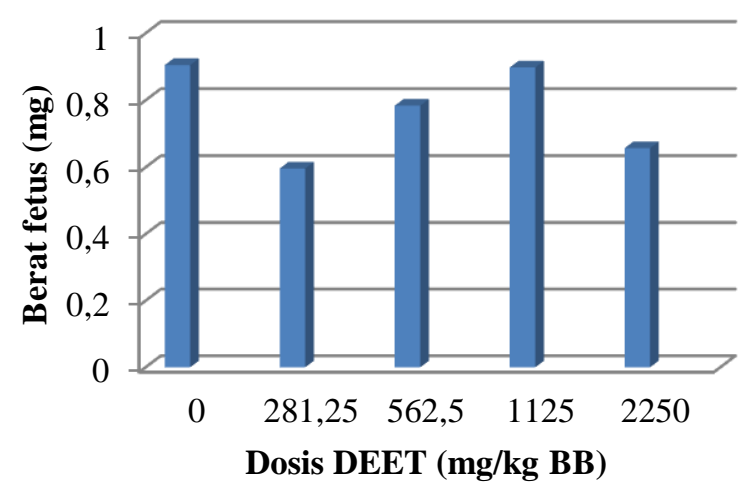

Gambar 1. Rata-rata berat fetus (mg) setelah pemberian berbagai dosis DEET

Dari hasil analisis varians satu jalur menunjukkan bahwa berat fetus setelah pemberian berbagai dosis DEET tidak terdapat perbedaan yang signifikan dengan $\mathrm{p}>0,05$.

Hasil penelitian menunjukkan bahwa setelah pemberian berbagai dosis DEET 0; 281,$25 ; 562,5 ; 1125$ dan $2250 \mathrm{mg} / \mathrm{kg}$ BB tidak ditemukan kelambatan penulangan pada tulang supraoksipital, kelainan jumlah tulang sternum, tulang vertebralis, tulang sakrokaudalis dan tulang phalanx anggota depan dan belakang. Hasil penelitian menunjukkan bahwa setelah pemberian berbagai dosis DEET 0; 281,25; 562,$5 ; 1125$ dan $2250 \mathrm{mg} / \mathrm{kg}$ BB tidak ditemukan kelambatan penulangan pada digit yang diketahui dari jumlah tulang phalanx anggota yang meliputi anggota depan dan belakang. 


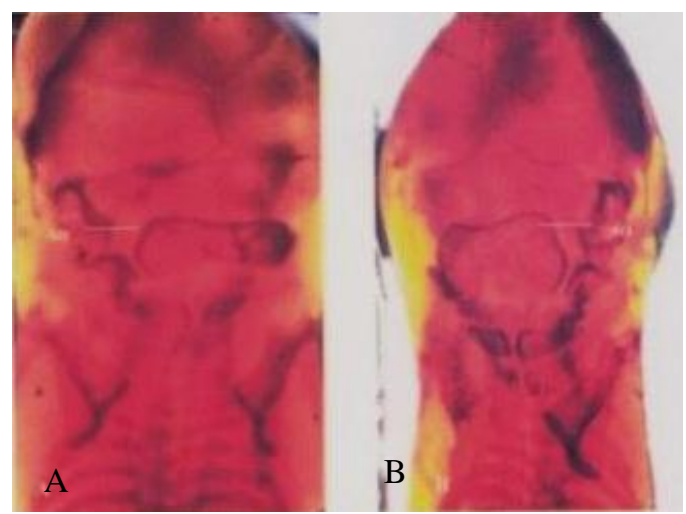

Gambar 2. Tulang supraoksipital fetus mencit (perbesaran 10x) $\mathrm{A}=$ Kontrol; B = Perlakuan dosis DEET $2250 \mathrm{mg} / \mathrm{kg} \mathrm{BB}$; so $=$ Tulang supraoksipital

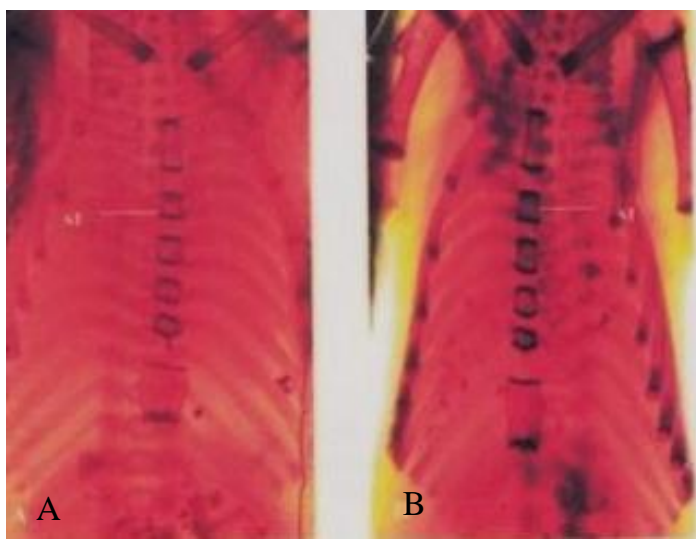

Gambar 3. Tulang sternum fetus mencit (perbesaran 10x) $\mathrm{A}=$ Kontrol; $\mathrm{B}=$ Perlakuan dosis DEET $2250 \mathrm{mg} / \mathrm{kg} \mathrm{BB}$; $\mathrm{st}=$ Tulang sternum

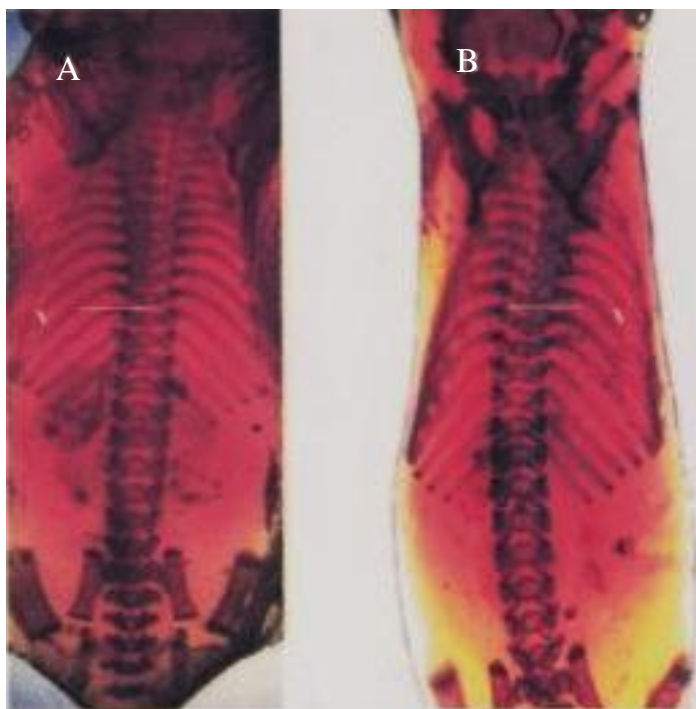

Gambar 4. Tulang vertebralis fetus mencit (perbesaran 10x) $\mathrm{A}=$ Kontrol; $\mathrm{B}=$ Perlakuan dosis DEET $2250 \mathrm{mg} / \mathrm{kg} \mathrm{BB} ; \mathrm{v}=$ Tulang vertebralis 


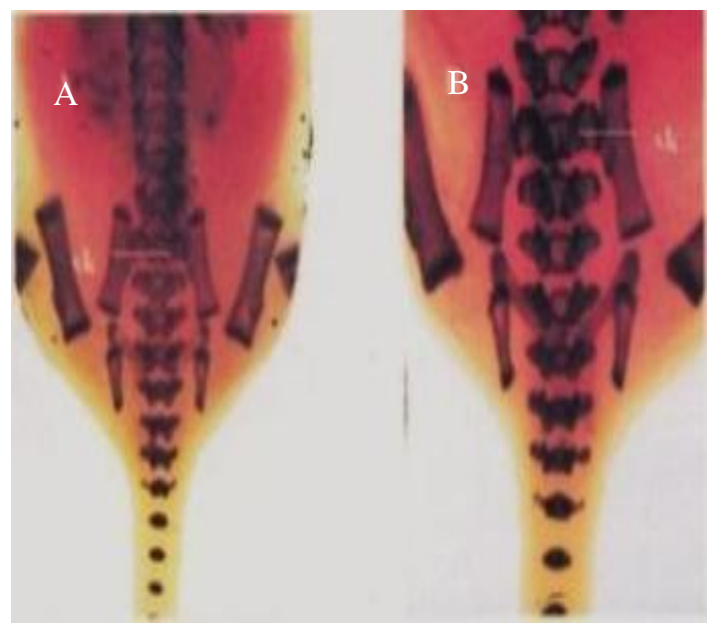

Gambar 5. Tulang sakrokaudalis fetus mencit (perbesaran 10x)

$\mathrm{A}=$ Kontrol; $\mathrm{B}=$ Perlakuan dosis DEET $2250 \mathrm{mg} / \mathrm{kg} \mathrm{BB}$; $\mathrm{sk}=$ Tulang sakrokaudalis

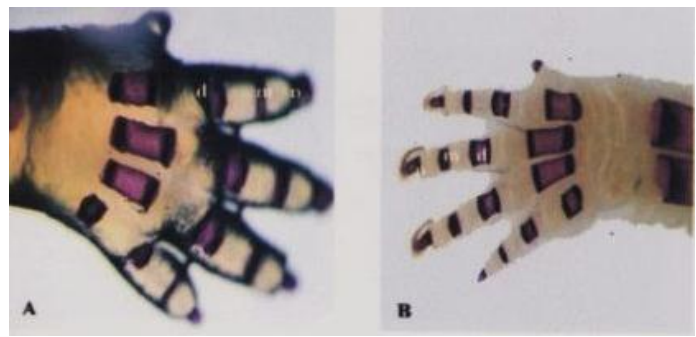

Gambar 6. Tulang phalanx anggota depan fetus mencit (perbesaran 10x)

$\mathrm{A}$ = Kontrol; B = Perlakuan dosis DEET $2250 \mathrm{mg} / \mathrm{kg} \mathrm{BB}$; $\mathrm{p}=$ prosimal $; \mathrm{m}=$ median $; \mathrm{d}=$ distal

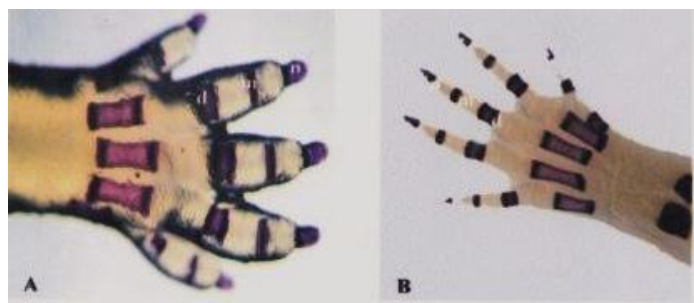

Gambar 7. Tulang phalanx anggota belakang fetus mencit (perbesaran 10x)

$\mathrm{A}=$ Kontrol; B = Perlakuan dosis DEET $2250 \mathrm{mg} / \mathrm{kg} \mathrm{BB}$; $\mathrm{p}=$ prosimal $; \mathrm{m}=$ median $; \mathrm{d}=$ distal

Pemberian berbagai dosis DEET tidak ditemukan kelainan rangka yang meliputi kelambatan penulangan pada tulang supraoksipital, kelainan jumlah tulang sternum, tulang vertebralis, tulang sakrokaudalis dan tulang phalanx anggota depan dan belakang.

Hal ini sesuai dengan studi yang dilakukan pada kelinci bunting yang diberi DEET 0, 50, 100, 1000 atau $5000 \mathrm{mg} / \mathrm{kg} \mathrm{BB}$ dalam pelarut etanol pada tulang punggung tercukur pada umur kebuntingan ke-0 - 29 hari. Hasil penelitian tersebut menunjukkan bahwa tidak ada peningkatan kejadian anomali skeletal ataupun jaringan lunak yang diamati pada kelompok perlakuan dan kontrol (Anonim ${ }^{1}$, 2002).

\section{KESIMPULAN}

Dapat disimpulkan bahwa pemberian DEET $0 ; 281,25 ; 562,5 ; 1125$ dan $2250 \mathrm{mg} / \mathrm{kg}$ BB pada umur kebuntingan ke-6 - 15 hari pada kulit dorsal mencit strain Balb/C tidak menyebabkan kelainan rangka fetus yaitu kelambatan penulangan pada tulang supraoksipital, kelainan jumlah tulang sternum, tulang vertebralis, tulang sakrokaudalis dan tulang phalanx anggota.

\section{DAFTAR PUSTAKA}

Anonim $^{1}$. 2002. DEET. Extension Toxicology Network (EXTOXNET). (Online). 
(http://pmep.cce.cornell.edu/profiles/Ext oxnet/carbaryl-dicrotophos/deet-ext. html. Diakses pada 27 November 2003.

Anonim $^{2}$. 2002. Insect Repellent. The Poison Center. (Online). (http://www.mnpoison. org/mnpoison/pdfs/Insect\%20Repellent. pdf. Diakses pada tanggal 27 November 2003.

Anonim $^{3}$. 2002. DEET (Insect Repellent). West Nile Virus $(W N V)$. (Online). (http://212.187.155.84/wnv/List_WPMo d_Cont/westnile/Chemical?Deet.htm. Diakses pada tanggal 27 November 2003.

Anonim ${ }^{1}$. 2003. Obat Nyamuk Bakar Indonesia Berbahaya?. Kalbe. (Online). (www.

kalbe.co.id/kfportal.nsf/0/865fd77ad7b3 9d447256da40003a7c8?OpenDocument \&AutoFramed-17k. Diakses pada tanggal 2 Desember 2003.

Anonim $^{2}$. 2003. Jangan Asal Semprot. Intisari, (Online). Kamis, 11 September 2003, (http://www.indomedia.com/intisari/Inti sari.cdf. Diakses pada tanggal 2 Desember 2003.

Anonim $^{3}$. 2003. Jangan Remehkan Efek Negatif Anti-Nyamuk!. Suara Karya. Kamis, 11 September 2003.

Anonim ${ }^{4}$. 2003. Bug Repellent and Pregnancy. Missouri Teratogen Information Services (MOTIS). (Online). (http://www.gnetics. missouri.edu/motis/bud_repellent_and_p regnancy.htm. Diakses pada tanggal 27 November 2003.

Cecchine, G., Beatrice A. Golomb, Lee H. H., Dala M. Spektor, C. Ross Anthony. 2002. DEET . A Review of the Scientific Literature as it Pertains to Gulf War Illness, (Online), Volume 8, (pecticide.

www.fwjustice.org./EHP\%/20Training/c hap\%205\%20repro.pdf. Diakses pada tanggal 27 November 2003.

Fradin, M. S. 1998. Mosquitoes and Mosquito Repellents: A Cliniician's Guide. Annals of Internal Medicine. (Online). (http://www.acponline.org/journals/anna 1s/01jun98/mosquito.htm. Diakses pada tanggal 25 Desember 2003.

Pergament, E. and Amy S. R. 1992. Insecticides. Illinois Teratogen Information Services (ITIS), (Online), (http://www.fetalexposure.org/INSECT. html. Diakses pada tanggal 27 November 2003.

Pronczuk, M. D. 1990. Pesticide Documents (PDs) DEET. INCHEM. (Online). (http://www.inchem.org/document/pds/p ds/pest80_e.htm. Diakses pada tanggal 27 November 2003. 